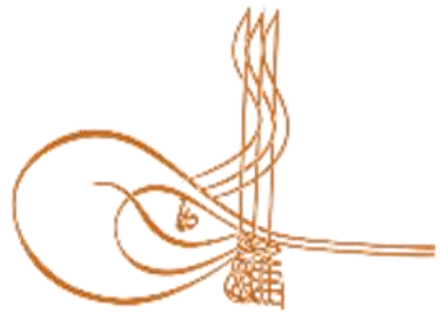

www.turkishstudies.net/social
Turkish Studies - Social Sciences

eISSN: $2667-5617$

Research Article / Araștırma Makalesi

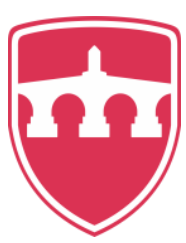

INTERNATIONAL

BALKAN

UNIVERSITY

Sponsored by IBU

\title{
Nepotizm ve Örgütsel Sinizm İliş̧kisi Üzerine Bir Araştırma
}

A Research on the Relation Between Nepotism and Organizational Cynicism

\author{
Musa Şanal ${ }^{*}$ - Emin Y1lmaz
}

\begin{abstract}
The human beings must work to afford their needs and have better life standards. The working places consist of more than one worker mostly. This situation leads us to examine organizational issues. As a matter of fact, this study examines nepotism and organizational cynicism and the relationship between them. Nepotism is the situation where people who do not have the qualifications required by the job are employed or promoted only on the basis of kinship relations. Organizational cynicism expresses the negative thoughts of the individual about his organization. The aim of this study is to examine the relationship of nepotism with the dimensions of organizational cynicism, cognitive, affective and behavioral dimensions. For this purpose, data was collected by discussing with the employees of the regional directorate and affiliated units of a public institution in Seyhan District of Adana Province. According to the findings obtained as a result of the research, a significant and inverse relationship was found between nepotism and the cognitive dimension of organizational cynicism. However, no relation was found between nepotism and the affective and behavioral dimensions of organizational cynicism. Turkey is in the public reception staff made the exam, nepotism does not constitute a serious problem in hiring. However, in the stages after recruitment, for example; In processes such as promotion and rewarding, decisions taken as a result of nepotist influence rather than merit are observed. The research has been made for existing employees and all of the participants experience basic processes such as promotion and reward. In this context, research; Is there a perception of nepotism in postemployment processes? If so, did this perception have an impact on the cynicist? focused on questions. However, when the available data were examined, the existence of such a relationship was rejected, except for the partial acceptance of a hypothesis in the public institution subject to the study.
\end{abstract}

Structured Abstract: Nepotism in any working environment, kinship, etc. Due to its bond, it is the case of creating a job regardless of the level of merit of a person or losing the person in the current work order, giving the person some privileges. Nepotism, which is an ongoing concept from past to present, has the

\footnotetext{
* Dr. Öğr. Üyesi, Çukurova Üniversitesi İ̈BF İşletme Bölümü

Asst. Prof. Dr., Cukurova University Department of Business Administratıon

ORCID 0000-0002-7996-2282

msanal@cu.edu.tr

** Pazarlama Yöneticisi, Turkiye Halk Bankası Adana Bölge Müdürlüğü

Marketing Manager, Turkey Halk Bank Adana Regional Directorate

ORCID0000-0002-6829-2658

eminyilmaz0106@hotmail.com

Cite as/ Atıf: Şanal, M., Yılmaz, E. (2020). Nepotizm ve örgütsel sinizm ilişkisi üzerine bir araştırma, Turkish Studies

- Social, 15(1), 661-676. https://dx.doi.org/10.29228/TurkishStudies.39905

Received/Geliş: 26 November/Kasım 2019

Checked by plagiarism software

Accepted/Kabul: 25 February/Şubat 2020

Published/Yayın: 29 February/Şubat 2020

Copyright (C) INTAC LTD, Turkey

CC BY-NC 4.0
} 
potential to reveal some side effects in organizations. One of these side effects is the concept of organizational cynicism. Organizational cynicism is a negative stance that the person feels against the organization he works with, an attitude defined by frustrations, insecurity and frustration, such as humiliation and insecurity towards one's organization, other things in the business environment, and its managers. In general cynicism, being cynic is caused by one's own personality traits, while being cynical in organizational cynicism comes from organizational elements. As a result of organizational cynicism, employees develop negative thoughts, emotions and behaviors towards the organization (Ery Yeşil \& Fındık, 2011; Tokgöz \& Yılmaz, 2008; Gül \& Ağıröz, 2011: 28).

Dean et al. (1998), organizational cynicism; They evaluated this concept in three dimensions by expressing it as "negative / negative attitude developed by the individual against the organization they work with". These dimensions are:

Cognitive Dimension; the belief that the organization lacks integrity,

Affective Dimension; negative attitude towards the organization,

Behavioral Dimension; to show contemptuous actions and critical behaviors that despise the organization.

The aim of this study is to examine the relationship of nepotism with the dimensions of organizational cynicism, cognitive, affective and behavioral dimensions. This study is important in terms of examining the concepts of nepotism and organizational cynicism, which are among the most inefficient causes of today's businesses, and providing suggestions on this subject. If these perceptions of employees are removed, organizational sense of belonging will increase and as a result, the performance of the organization will increase. In this study, the cognitive, behavioral and affective dimensions of nepotism and organizational cynicism are primarily investigated theoretically. In this part of the study, which will examine the relationship between nepotism and organizational cynicism dimensions (cognitive, affective and behavioral), the research model and hypotheses will be included. Then, analysis methods and results applied on the collected data to test the research hypotheses will be shared.

Public banks in Adana Province were the main mass of the research. The sample consists of 88 employees working in the regional directorate and affiliated units of a public bank in Seyhan District of Adana province. In the study, survey method was used as data collection method. The main reason for choosing the public bank for research is the perception that the presence of nepotist actions in the public sector may be higher than the private sector. This situation can be seen more in processes such as promotion and rewarding, especially after recruitment takes place. The hypotheses of the research model are as follows:

H1: There is a significant relationship between nepotism and the cognitive dimension of organizational cynicism. For the sample of the study, there is a significant relationship between nepotism and the cognitive dimension of organizational cynicism and it is opposite. The hypothesis has been partially accepted. As nepotism increases, the cognitive dimension of organizational cynicism decreases. Likewise, as the cognitive dimension of organizational cynicism rises among the employees, it appears that nepotism is less present. In other words, employees of nepotism consider it partially acceptable in terms of forming their own internal working groups.

H2: There is a significant relationship between nepotism and the affective dimension of organizational cynicism. Hypotheses were rejected because the applied one-way analysis of variance P was> 0.05. The calculated correlation coefficient was found meaningless to support the variance analysis result. For the sample of the study, no significant relationship was found between nepotism and the affective dimension of organizational cynicism. The hypothesis was rejected. From this point of view, it is seen that nepotism does not cause any change in the way in which employees express their feelings or their sincerity.

H3: There is a significant relationship between nepotism and behavioral dimension of organizational cynicism. Hypothesis was rejected because the one-way variance analysis $\mathrm{P}$ value $>0.05$ was applied. The calculated correlation coefficient was found to be low (-0.089) to support the variance analysis result. No significant relation was found between nepotism and behavioral dimension of organizational cynicism for the sample of the study. The hypothesis was rejected. In this context, in the sample of the study, it can be said that nepotism does not cause an attempt to show humiliating or insignificant value to the employees' behavior towards the institution.

Turkish Studies - Social, 15(1) 
Participants are public personnel. Since recruitment of public personnel is done through exams in our country, nepotism does not pose a serious problem. However, especially in the public sector after the recruitments, for example; In processes such as promotion and rewarding, decisions taken as a result of nepotist influence rather than merit are seen. The research has been made for existing employees and all of the participants experience basic processes such as promotion and reward. In this context, research; Is there a perception of nepotism in post-employment processes? If so, did this perception have an effect on cynicism on the employee? focused on questions. However, when the available data were examined, the existence of such a relationship was rejected, except for the partial acceptance of a hypothesis in the public institution subject to the study. On the other hand, the low risk of dismissal of public employees compared to private sector employees may cause public employees to develop less cynical thoughts, feelings and behaviors compared to private sector employees. It is seen that the responses of the participants to the nepotism scale are in the range of 2.94-3.8, in other words, they do not experience a very severe nepotism. The rejection of two of the three hypotheses showing the relationship between nepotism and cynicism can be explained to some extent by the fact that the participants did not experience nepotism very violently. At this point, it can be interpreted that the sample consists of the regional directorate employees and that this section feels less nepotism and cynicism due to the merit of the work done, and with the influence of professional management.

Keywords: Nepotism, Organizational Cynicism, Cognitive Dimension, Affective Dimension, Behavioral Dimension

JEL: M10, M12.

Öz: İnsanoğlu ihtiyaçlarını karşılamak ve daha iyi bir yaşam düzeyine sahip olabilmek için çalışmak zorundadır. Çalışma hayatı yapılan işin doğası gereği çoğu zaman birden fazla bireyi kapsamaktadır. Bu durum bizleri örgütsel konuları incelemeye yöneltmektedir. Nitekim bu çalışmada da söz konusu konulardan nepotizm ve örgütsel sinizm ile aralarındaki ilişki incelenmektedir. Nepotizm, işin gerektirdiği niteliklere sahip olmayan kişilerin sadece akrabalık ilişkileri esas alınarak istihdam edilmesi veya terfi ettirilmesi durumudur. Örgütsel sinizm ise, bireyin örgütü hakkındaki olumsuz düşüncelerini ifade etmektedir. Bu çalışmanın amacı, nepotizmin, örgütsel sinizmin boyutları olan bilişsel, duyuşsal ve davranışsal boyutlarla iliş̧isini incelemektir. Bu amaçla Adana İli Seyhan İlçesi'ndeki bir kamu kuruluşunun bölge müdürlüğü ve bağlı birimlerindeki çalışanlar ile görüşülerek veriler toplanmıştır. Araştırma sonucunda elde edilen bulgulara göre nepotizm ile örgütsel sinizmin bilişsel boyutu arasında anlamlı ve ters yönlü bir ilişkiye rastlanmıştır. Bununla birlikte, nepotizm ile örgütsel sinizmin duyuşsal ve davranışsal boyutları arasında bir ilişkiye rastlanmamıştır. Araştırmaya katılanlar kamu personelidir. Türkiye'de kamu personeli alımı sınavla yapılmakta olup, işe alımda nepotizm ciddi bir sorun teşkil etmemektedir. Ancak işe alımlardan sonraki aşamalarda örneğin; terfi, ödüllendirme gibi süreçlerde liyakatten ziyade nepotist etki sonucunda alınmış kararlar görülmektedir. Araştırma mevcut çalışanlara yapılmış olup katılımcıların tümü terfi, ödül gibi temel süreçleri yaşamaktadır. Bu bağlamda araştırma; işe alım sonrası süreçlerde nepotizm algısı var mı? Eğer var ise bu algının çalışan üzerinde sinizm açısından bir etkisi olmuş mu? sorularına odaklanmıştır. Ancak eldeki veriler incelendiğinde araştırmaya konu edilen kamu kurumunda bir hipotezin kısmen kabulü dışında böyle bir ilişkinin varlı̆̆ reddedilmiştir.

Anahtar Kelimeler: Nepotizm, Örgütsel Sinizm, Bilişsel Boyut, Duyuşsal Boyut, Davranışsal Boyut.

\section{Giriş}

Latince dilinde yeğen demek olan "nepos" sözcüğünden türeyen ve İtalyancada "nepotismo" diye ifade edilen nepotizm kavramı, ilk olarak papaların aile mensuplarını kayırması ile ortaya çıkmıştır (Kiechel, 1984: 143-144; Büte, 2011: 383-384). Nepotizm herhangi bir çalışma ortamında, akrabalık vb. bağı nedeniyle, bir kişiye liyakat düzeyi dikkate alınmaksızın istihdam yaratılması veya mevcut iş düzeninde kişinin kayrılması, kişiye birtakım imtiyazlar tanınması durumudur. Geçmişten günümüze süregelen bir kavram olan nepotizm, örgütlerde bir takım yan etkileri ortaya çıkarma potansiyeline sahiptir. Bu yan etkilerden biri örgütsel sinizm kavramıdır. Örgütsel sinizm, kişinin çalıştığı örgüte karşı beslediği negatif bir duruş olup, kişinin örgütüne, iş 
ortamındaki diğer şeylere ve yöneticilerine karşı aşağılama ve güvensizlik gibi hayal kırıklıkları, engellenmiş olma düşüncesi ve umutsuzluk ile tanımlanmış bir tutumdur. Genel sinizmde, sinik olma kişinin kendi kişilik özelliklerinden kaynaklanırken, örgütsel sinizmde sinik olma örgütsel unsurlardan ileri gelmektedir. Örgütsel sinizm sonucunda çalışanlar örgüte karşı olumsuz düşünce, duygu ve davranışlar geliştirmektedirler (Eryeşil ve Fındık, 2011; Tokgöz ve Y1lmaz, 2008; Gül ve Ağıröz, 2011: 28).

\section{Nepotizm ve Örgütsel Sinizm Kavramı}

$\mathrm{Bu}$ bölümde nepotizm ve örgütsel sinizm kavramları tanımlanarak, her iki kavramın belirgin özelliklerine değinilecektir.

\subsection{Nepotizm}

Erdem ve Özkanan (2014) nepotizm veya akraba kayırmacılığını şu şekilde açıklamaktadır: $\mathrm{Bu}$ kavramlar söz konusu ise bireyin bir göreve getirilmesi için nitelikleri dikkate alınmamakta, bunun yerine bürokrat, politikacı ve üst düzey yöneticilerle olan akrabalık ilişkileri devreye girmektedir.

Nepotizmde yapılacak işe göre kişi seçilmez. Birey göz önünde bulundurularak iş seçilir. Nepotizm bir tür çıkar çatışması niteliğindedir. Nepotist tavır sergileyen kişi kurum içindeki gücü sayesinde, ehliyet sahibi olup olmadıklarını dikkate almaksızın aynı kan bağı taşıyan kişilere iş ortamında pozisyon oluşturur veya kariyer basamaklarında pozitif ayrımcılık yapar (Karakaş ve Çiçek, 2009: 52). Bu anlayış kapsamında oluşan nepotist tutumlar, bireylerin akrabalarına ayrıcalıklı olarak davranmasına neden olmaktadır.

Nepotizm gerek kamu sektöründe gerekse özel sektörde daha çok aile işletmelerinde görülen en önemli sorunlardan biridir. Kamu sektörünün kronik hastalıklarından biri olan yolsuzluğun alt dallarından birisi olan nepotizm, anlam olarak "memurluğu işe girişte ve yükselişte siyasal kayırmanın ve memuriyet kadrolarının bir ganimet gibi yandaşlar arasında dağıtılması, siyasi ödüllendirmenin ve partizan kadroları oluşturmanın yolu" olarak bilinmektedir. Kayırmacılık sadece siyasal eğilim bakımından değil aynı zamanda hemşericilik, aynı kulübün üyesi olmak, aynı okuldan mezun olmak gibi nedenlere de dayanabilmektedir. Kamu yönetimi sistemini olumsuz yönde etkileyip tarafsızlık ilkesinden saplamalara neden olan kayırmacılık dört ana başlık altında toplanmaktadır (Yıldırım, 2013: 358-360)

- Birincisi adam kayırmacılığıdır. Buna göre kamuda yapılan atamalarda liyakat ilkesinin yerini akrabalık, hemşericilik, arkadaşlık gibi şahsi faktörler almaktadır.

- İkincisi ise siyasal partilerin iktidara geldikten sonra kendilerini desteklemiş olan seçmenlere çeşitli şekillerde ayrıcalıklı işlem yaparak haksız yere menfaat sağlamalarını sağlayan siyasal kayırmacılık ve patronajdır.

- Üçüncüsü ise hizmet kayırmacılığı olup, siyasal iktidarın iktidarı kaybetmemek için kontrol altında tuttukları ekonomik gücü, oylarını arttıracak şekilde seçim bölgesine tahsis etmesidir.

- Sonuncu tür ise, gönül yapma, diye tanımlanmaktadır ve siyasal iktidarın seçim öncesinde kendisine yardımcı olan bazı partizan gruplara seçim sonrasında devletin imkânlarından daha çok yararlanmalarını ifade etmektedir.

Kamu ve özel sektörlerde nepotist davranışların ilk kurbanı kurallardır. Örneğin, ödüllendirme sisteminde hak edenin yerine kayrılan tercih edilebilir. Diğer taraftan kamu açısından değerlendirdiğimizde; ikinci kurban halktır çünkü devletin tüm vatandaşlarına eşit olarak davranması beklenmektedir. Bir kamu sektörü çalışanı kendi yakınını kayırdığında, bir işe girmek için daha kaliteli olan veya ihale için daha iyi bir teklif sunabilen tüm diğer adayların hakları etkilenir (Büte, 2011: 387). Özel sektörde ise kayırmacılık en sık aile işletmelerinde görülmekte 
olup, aile işletmelerinin birçoğunda liyakate bakılmaksızın aile üyelerine kilit pozisyonlarda görev verilmektedir. Bu durum da, örgüt içinde aile dışı çalışanların olumsuz etkilenmesine ve örgütün kurumsallaşamamasına neden olmaktadır.

Aile işletmelerinde nepotizm sıklıkla görülen bir durumdur. Bilhassa kurulduğu ilk senelerde bu kuruluşlarda aileden kişiler işe alınmakta, kuruluşlar büyüdükçe ve çalışan sayısı arttıkça, aile üyeleri idareci konumuna yükselmektedir. İleriki dönemlerde ise aile kuruluşları devamlılıklarını sağlamak için profesyonel çalışan ve idarecileri de istihdam edebilmektedir. Bu kapsamda küçük aile işletmelerinde nepotizmin daha sıklıkla uygulandığı söylenebilmektedir. Bununla birlikte, bu tür işletmelerin genel olarak kurumsallaşmamış olmalarından, kuruma hâkim olan ve herkesin uyması gerekli kurallar bulunmamaktadır. Böyle bir durum, kurum içinde belirsizliği meydana getirmektedir. Rakiplerin stratejilerinin bilinmediği bir durumda, sahip durumunda olan idareci, aile kuruluşunu "ortak kaynak" olarak algılamakta ve bu kaynaktan olabildiğince en büyük yararı sağlamayı hedef edinmektedir (Polat, 2012: 26).

Özüren (2017) nepotist uygulamaların olumsuzluklarını şu şekilde ifade etmiştir:

- Nepotizmin şirketin gelişimine engel olarak israfi teşvik etmesi,

- Yetersiz bireylerin salt akrabalık ilişkilerine dayanarak istihdam ya da terfi ettirilmesi,

- Nepotist uygulamalar sonucunda gelişen önyargıların işletmenin bütününe mal edilmesi sonucunda çalışanların her gelişime şüpheyle yaklaşması,

- İstenmeyen uyuşmazlıklar sonucunda şirketin aleyhine hukuki süreçlerin olması,

- Nepotizmin çeşitlilikleri baskılayıp, yeni fikir ve bakış açılarının örgütün karar verme sürecine dâhil olmasına engel teşkil etmesi,

- Aralarında akrabalık bağı olan çalışanların işletme yararını ikincil düzeyde görerek aile üyelerinin lehine firsatçı uygulamalara geçilmesi.

\section{2. Örgütsel Sinizm}

Günümüzde sinizm, bireylerin yalnızca kendi çıkarlarını gözlemlediğine ve herkesi çıkarcı olarak kabul ettiğine inanan düşüncedir. Sinizmin "şüphecilik", "güvensizlik", "inançsızlık", "karamsarlık" ve "olumsuzluk" ile yakın anlamları olsa da, bireyin "kusurlu, güçlü olumsuz duyguları yanında, küçümseme, öfke, sinirlilik, utanç vb. duygusal öğelerin tanımlanması ile beraber temel inanç, dürüstlük, adalet ve samimiyetin kişisel çıkarlara feda edildiğidir (James, 2005).

Sinizm ile ilgili bütün tanımlamalar sonucunda en çok bireyi etkileyen bir konu olduğu açıkça görülmektedir. Ancak bireyi örgütlerden ayırmanın çok zor olduğu bir dünyada örgütsel sinizm konusu da önemli bir zemine sahip olmaktadır. Son yıllarda örgütsel davranış alanının önem kazanmasıyla örgütsel sinizm kavramı da öne çıkmıştır. Örgütsel sinizm, kişinin örgütüne, iş ortamındaki diğer şeylere ve yöneticilerine karşı aşağılama ve güvensizlik gibi hayal kırıklıkları, engellenmiş olma düşüncesi ve umutsuzluk ile tanımlanmış bir tutumdur. Örgütsel sinizm, kişilerin örgütlerine yönelik bilişsel, davranışsal ve duyuşsal negatif tutumları olarak tanımlanabilir (Eryeşil ve Fındık, 2011). Örgütsel sinizm, kişinin çalıştığı örgüte karşı beslediği negatif bir duruştur. Örgütsel sinizm ile genel sinizm yapı bakımından birbirinden farklı kavramlardır. Yani, genel sinizmde, sinik olma kişinin kendi kişilik özelliklerinden kaynaklanır ancak örgütsel sinizmde sinik olma örgütsel unsurlardan ileri gelmektedir (Tokgöz ve Yılmaz, 2008).

Örgütsel sinizm, çalışanların örgütlerinin dürüstlükten yoksun olduğuna inandığında ortaya çıkar. Bu dürüstlük eksikliği algısı, adalet, ahlak ve doğrulukla ilgili temel beklentilerin ihlal edildiği duygusundan kaynaklanabilir. Örgütsel alaycıllğın deneyim yoluyla gelişen öğrenilmiş bir düşünceyi temsil ettiği de tartışılmaktadır (Johnson ve O'leary-Kelly, 2003: 629). 
Bir başka tanıma göre ise örgütsel sinizm, bir iş görenin örgütüne karş1 geliştirdiği olumsuz davranışlar olarak tanımlanmaktadır. Örgütün dürüst olmadığına dair inanç, örgüte yönelik negatif duygu ve bu inançlar ve duygularla paralel olarak, örgüte yönelik eleştirel davranma eğilimi olmak üzere üç taraflı bir tutum olarak belirtilmektedir (Dean vd., 1998: 345).

\subsection{1. Örgütsel Sinizmin Boyutları}

Dean vd. (1998), örgütsel sinizmi; "bireyin çalıştığ 1 örgüte karşı geliştirdiği negatif/olumsuz tutum" olarak ifade ederek bu kavramı üç boyutta değerlendirmişlerdir. Bu boyutlar:

•Bilişsel Boyut; örgütün dürüstlükten yoksun olduğu inanc1,

•Duyuşsal Boyut; örgüte karşı geliştirilen negatif tutum, göstermektir.

-Davranışsal Boyut; örgüte karşı hor gören, aşağılayıcı eylemler ve eleştirel davranışlar

\subsubsection{1. Örgütsel Sinizmin Bilişsel Boyutu}

Örgütsel sinizmin ilk boyutu, örgütün dürüstlükten yoksun olduğu inancıdır. Oxford İngilizce Sözlüğü'nde dürüstlük, ahlaki kurallarda sağlamlık, bozulmamış bir erdemli karakter, özellikle gerçeklik, adalet arasındaki ilişki hakkında dürüstlük ve samimiyet ile karakterizedir. Örgütsel sinizmin sözlük tanımını bu bilgilerle ilişkilendirirsek; sinizm insanı harekete geçiren amaç ve eylemlerde samimiyet ve iyiliğe olan inançsızlığın mizacı olarak ifade edilir. Bu nedenle, kurumsal sinizm, çalıştıkları organizasyonun adalet, dürüstlük ve samimiyet ilkelerinden yoksun olan uygulamalarına dayanır. Sinikler ayrıca, bu ilkelerin çoğu zaman kişisel çıkarlara feda edildiğini ve ahlaksız davranışların standart olduğunu kabul edebilir. Sinikler çoğu zaman eylemlerin arkasında gizli nedenlerin olduğunu düşünürler (Dean vd, 1998).

Bilişsel boyut ile örgütsel sinizm arasındaki ilişki incelenirse, örgütlerinde sinik tutuma sahip bireylerin aşağıdaki inançlara sahip oldukları gözlemlenir (Gövez, 2013:22):

- Yönetimin direktifleri önemsenmez.

- Söylem ve eylem bağdaşmamaktadır.

- Örgütlerde çalışanlar hileye başvurabilir, yalan söyleyebilir.

- Örgütlerdeki insan davranışları tutarsız ve güvenilmezdir.

- Örgüt içinde bireysel çıkarlarla doğru orantılı ilişkiler ağı mevcuttur. Bu durumda vicdansız ve ahlaksız davranışlar gösterilmesi, çalışanların kendi menfaatleri için içtenlik, dürüstlük ve doğruluk gibi değer yargılarını ihmal etmesi ile ilgilidir.

Sonuç olarak bilişsel boyut başkalarına güvenilemeyeceğini; başkalarının vicdansız olduğunu ve bir şey isteme nedenlerini kendilerine saklamaları gerektiğini barındırır (Gövez, 2013:22).

\subsubsection{2. Örgütsel Sinizmin Duyuşsal Boyutu}

Örgütsel sinizmin bu boyutunda, örgüte karşı olumsuz tutumlar duygusal tepkilerden oluşur. Duygusal cevap dokuz temel duygudan oluşur. Bu duygular, heyecan, neşe, mutluluk, sıkıntı, öfke, iğrenme, hor görme, korku ve utançtır.

Siniklerin sadece örgütleri hakkında bazı inançları olmadığı, aynı zamanda bu inançlar hakkında bazı duyguları olduğu da görülebilir (Dean vd, 1998). Sinizmi deneyimleyen bireyler, daha bilgili oldukları veya doğru davranışı daha iyi anladıkları hissine sahiptirler. Sinikler her zaman gizli neden arayışına sahip oldukları için içtenlik ya da dürüstlük yerine farklı yolları deneyerek hareket etmeyi tercih etmektedir. 


\subsubsection{3. Örgütsel Sinizmin Davranışsal Boyutu}

Örgütsel sinizmin son boyutu davranışsal boyuttur ve kuruma karşı olumsuz ve sıklıkla aşağılayıcı davranışlar sergilenir. Örgüt üyeleri, örgütle ilgili bilgileri olumsuz şekilde çevrelerine ileterek ve kuruluştan şikâyet ederek eleștirel davranırlar. Örgütlerde sinik davranışı olan bireyler örgütün gelecek planları hakkında karamsar ifadeler çizme, kötümser tahminlerde bulunma ve bu noktada sinik bir tarza sahip olma eğilimindedir. Kuruluşa karşı aşağılayıcı ifadelerle dolu bir dil kullanırlar. Sinik davranıșları ifade etmek için çalıșanlar mizah, özellikle alaycı mizah sunar. Bu nedenle, alaycı tutumları olan bireyler, kuruluşlarının amaçları ile alay edebilir, görev beyanlarını yeniden yazabilir ve alaycı yorumlar yapabilir. Örgütlerde sözel olmayan davranışlar da sinik olabilir. Çalışanların birbirlerine anlamlı bakmaları, gülünç ve küçümser davranmaları sinik davranışların örnekleridir (Polatcan, 2012:13).

\subsection{Nepotizm ve Örgütsel Sinizm İlişkisi Üzerine Yapılan Çalışmalar}

$\mathrm{Bu}$ bölümde nepotizm ve örgütsel sinizm ilişkisi üzerine yapılan çalışmalara yer verilmiş olup, bu çalışmalar ve amaçları aşağıdaki tabloda sunulmuştur.

Tablo 1: Nepotizm ve Örgütsel Sinizm Üzerine Yapılan Çalıșmalar

\begin{tabular}{|c|c|c|}
\hline Çalışmanın Adı & Türü & Amacı \\
\hline $\begin{array}{l}\text { Sunman, G. (2017). Nepotizm ve psikolojik } \\
\text { sözleşme ihlalinin örgütsel sinizme etkisi: Aksaray } \\
\text { OSB'de bir uygulama (Yüksek Lisans Tezi, } \\
\text { Aksaray Üniversitesi Sosyal Bilimler Enstitüsü). }\end{array}$ & $\begin{array}{l}\text { Yüksek } \\
\text { Lisans Tezi }\end{array}$ & $\begin{array}{l}\text { Bu çalışmanın ana amacı; nepotizm } \\
\text { ve psikolojik sözleşme ihlalinin } \\
\text { örgütsel sinizme etkisinin olup } \\
\text { olmadığının belirlemek r ve } \\
\text { değişkenler arasındaki ilişkinin tespit } \\
\text { edilmesidir. }\end{array}$ \\
\hline $\begin{array}{l}\text { Özkoç, A. G., Kendir, H., Arslan, E., \& Özgün, N. } \\
\text { (2019) İşgörenlerin Nepotizm ve Sinizm Algıları } \\
\text { Arasındaki İlişki: Nevşehir'deki Otel } \\
\text { İşletmelerinde Bir Araştırma. }\end{array}$ & Makale & $\begin{array}{l}\text { Bu araştırma, Nevşehir'de faaliyet } \\
\text { gösteren 3, 4 ve } 5 \text { yildızlı otel } \\
\text { işletmelerindeki işgörenlerin örgütsel } \\
\text { nepotizm ve örgütsel sinizm algıları } \\
\text { arasındaki ilişkiyi ortaya koymak } \\
\text { amacıyla gerçekleştirilmiştir. }\end{array}$ \\
\hline $\begin{array}{l}\text { Abubakar, A. M., Namin, B. H., Harazneh, I., } \\
\text { Arasli, H., \& Tunç, T. (2017). Does gender } \\
\text { moderates the relationship between } \\
\text { favoritism/nepotism, supervisor incivility, cynicism } \\
\text { and workplace withdrawal: A neural network and } \\
\text { SEM approach. Tourism } \\
\text { Perspectives, 23, 129-139. }\end{array}$ & Makale & $\begin{array}{l}\text { Bu çalışma, kayırmacılığın çalışan } \\
\text { sinizmine ve işten çekilmeye etkisini } \\
\text { ve cinsiyetin 1lımlı rolünü } \\
\text { incelemektedir. Kesitsel bir tasarım } \\
\text { kullanılarak, Kuzey Kıbrıs'taki } 3 \\
\text { yıldızlı otellerde çalışanlardan veri } \\
\text { toplanmıştır. }\end{array}$ \\
\hline $\begin{array}{l}\text { Pelit, E., Dinçer, F. I., \& Kılıç, İ. (2015). The effect } \\
\text { of nepotism on organizational silence, alienation } \\
\text { and commitment: A study on hotel employees in } \\
\text { Turkey. Journal of Management Research, 7(4), } \\
\text { 82-110. }\end{array}$ & Makale & $\begin{array}{l}\text { Bu çalışmanın amacı, kayırmacılığın } \\
\text { örgütsel sessizlik, yabancılaşma ve } \\
\text { bağlılık üzerindekir etkisini } \\
\text { belirlemektir. Bu kavramlar örgütsel } \\
\text { sinizm sonucunda oluşan tutumlar } \\
\text { olarak ifade edilebilir. }\end{array}$ \\
\hline
\end{tabular}

\section{Yöntem}

$\mathrm{Bu}$ çalışmanın amacı, nepotizmin, örgütsel sinizmin boyutları olan bilişsel, duyuşsal ve davranışsal boyutlarla ilişkisini incelemektir. $\mathrm{Bu}$ çalışma, günümüz işletmelerinin birçoğunun verimsizlik nedenlerinin başında gelen nepotizm ve örgütsel sinizm kavramlarının incelenmesi ve bu konuda öneriler sunulması açısından önem arz etmektedir. Çalışanların bu algıları giderildiği takdirde örgütsel aidiyet hisleri artacak ve bunun sonucunda örgütün performans1 yükselecektir. Bu çalışmada nepotizm ile örgütsel sinizmin bilişsel, davranışsal ve duyuşsal boyutları öncelikle teorik olarak incelenmiştir. Nepotizmin, örgütsel sinizmin boyutları (bilişsel, duyuşsal ve davranışsal) ile 
ilişkisinin incelenmesine yönelik çalışmanın bu bölümünde öncelikle araştırma modeline ve hipotezlere yer verilecektir. Ardından araştırma hipotezlerini test etmek amacıyla toplanan veriler üzerinde uygulanan analiz yöntemleri ve sonuçlar paylaşılacaktır.

\subsection{Araştırma Modeli ve Hipotezler}

Araştırmanın ana kütlesini Adana İlinde yer alan kamu bankaları oluşturmuştur. Örneklemini ise, Adana ili Seyhan İlçesi’ndeki bir kamu bankasının bölge müdürlüğü ve bağlı birimlerinde görev alan toplam 88 çalışan oluşturmaktadır. Çalışmada, veri toplama yöntemi olarak anket yöntemi kullanılmıştır. Araştırma için kamu bankasının tercih edilmesinin temel nedeni kamu sektöründe nepotist eylemlerin varlığının özel sektöre göre daha çok olabileceği algısıdır. Özellikle işe alım geçekleştikten sonra terfi, ödüllendirme gibi süreçlerde bu durum daha çok görülebilmektedir. Bu amaçla oluşturulan araştırma modeli aşağıda verilmiştir.

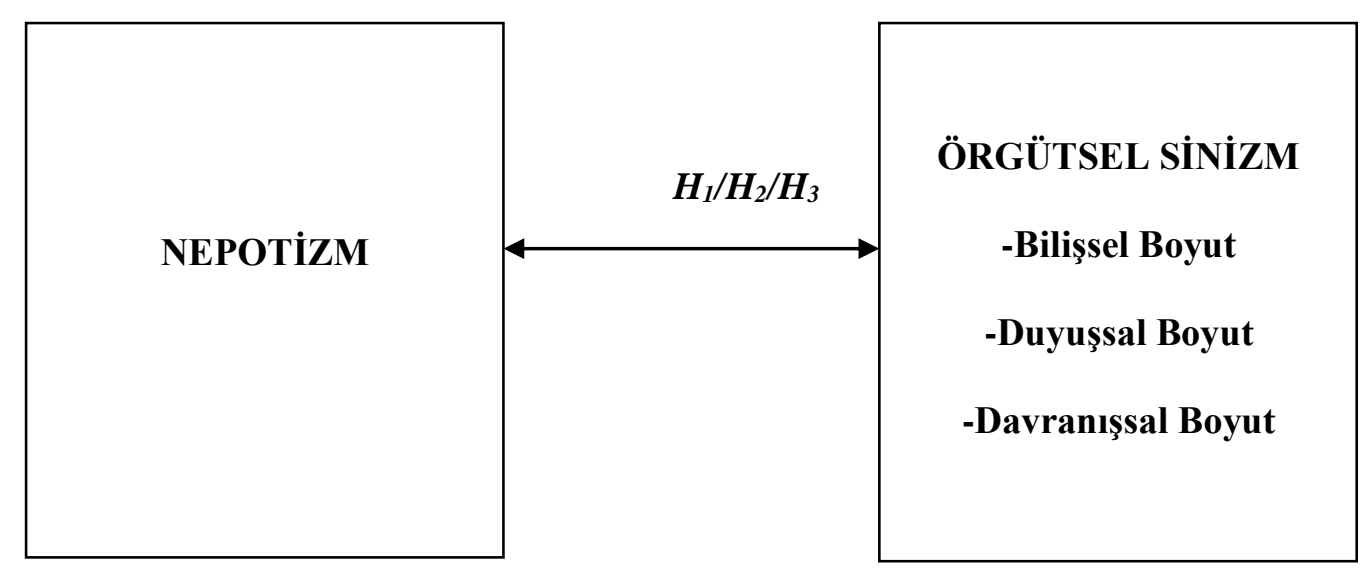

Şekil 1: Araştırma Modeli

Araştırma modelinin hipotezleri aşağıdaki gibidir:

$\mathrm{H}_{1}$ : Nepotizm ile örgütsel sinizmin bilişsel boyutu arasında anlamlı bir ilişki vardır.

$\mathrm{H}_{2}$ : Nepotizm ile örgütsel sinizmin duyuşsal boyutu arasında anlamlı bir ilişki vardır.

$\mathrm{H}_{3}$ : Nepotizm ile örgütsel sinizmin davranışsal boyutu arasında anlamlı bir ilişki vardır.

\subsection{Evren, Örneklem ve Ölçekler}

Araştırmanın ana kütlesini Adana İlinde yer alan kamu bankaları oluşturmuştur. Ana kütlenin büyüklüğü, zaman ve maliyet kısıtları gibi etkenlerin sonucunda örnekleme yöntemi olarak Gelişigüzel (Haphazard) Örnekleme Yöntemi kullanılmıştır. Gelişigüzel (Haphazard) Örnekleme Yöntemi; araştırmacının saptanan örneklem büyüklüğüne göre herhangi bir şekilde evrenin bir parçasını seçmesi (Kılıç, 2013: 45) olarak tanımlanabilir. Araştırmanın örneklemini, Adana ili Seyhan İlçesi’ndeki bir kamu bankasının bölge müdürlügü ve bağlı birimlerinde görev alan toplam 88 çalışan oluşturmaktadır. Bu çalışmada e-posta gönderimi ile 88 kişiye ulaşılmış, ancak 84 çalışan ankete dönüş yapmıştır. Dolayısıyla, anket dönüş oranı \%95 seviyesindedir.

Çalışmada nepotizmin Asunakutlu, T. \& Avcı, U. (2009) tarafindan geliştirilen ölçek ile ölçülmesi hedeflenmiştir. Sinizmin bilişsel, duyuşsal ve davranışsal boyutlarını ölçmek için ise Brandes P., Dharwadkar R. ve Dean J. (1999) ölçeği tercih edilmiştir.

2012 yılında Nevşehir Üniversitesi, İktisadi ve İdari Bilimler Fakültesi bünyesinde görevli araştırmacılar tarafindan "Brandes, Dharwadkar ve Dean'in (1999) Örgütsel Sinizm Ölçeği Türkçe Formunun Geçerlilik ve Güvenilirlik Çalışması: Kayseri Organize Sanayi Bölgesi Örneği” adlı bir 
çalışma yapılmıştır. Bu çalışmanın amacı, Brandes vd. (1999) tarafından geliştirilen örgütsel sinizm ölçeğinin dilimizdeki formatının geçerlilik ve güvenilirliğini araştırmaktır. Kayseri Organize Sanayi Bölgesi'nde yerleşik ve imalat sanayinde faaliyet gösteren tesislerde çalışan 300 katılımcıdan araştırma dataları elde edilmiştir. İç tutarlılık katsayıları ve madde-toplam puan korelasyonları konu ölçeğin güvenilirliğinin hesaplanmasında kullanılmıştır. Geçerlilik değerlendirmesinde, örgütsel sinizm ölçeğinin faktör yapısını göstermek için açımlayıcı ve doğrulayıcı faktör analizleri oluşturulmuştur. Faktör analizi sonuçlarına göre konu ölçeğin orijinal halinde olduğu gibi; duygusal, bilişsel ve davranışsal olmak üzere üç boyutlu bir yapı ortaya koyduğu ve Türk örnekleminden elde edilen verilerle de bu boyutların doğrulaması söz konusu olmuştur. Ölçeğin iç tutarlılık katsayıları ölçek geneli için 0,91, duygusal alt boyut için 0,94, bilişsel alt boyut için 0,87 ve davranışsal alt boyut için 0,82 olarak hesaplanmıştır. Elde edilen sonuçlara göre, örgütsel sinizm ölçeğinin Türkiye'deki ilgili örneklem grubundan toplanan verilere göre geçerlilik ve güvenilirliğe sahip olduğu kanaatine ulaşılmıştır.

$\mathrm{Bu}$ çalışmada anketin ilk bölümü demografik sorulardan, ikinci bölümü nepotizm ölçeğinden, üçüncü ve son bölümü ise sinizm ölçeğinden oluşmaktadır. İlk bölümde personellerin cinsiyet, yaş, medeni durum, öğrenim durumu ve çalışma yılını kapsayan, bireysel özellikler içeren 5 soru yer almaktadır. İkinci bölümde personellerin nepotizm düzeylerinin belirlenmesine yönelik hazırlanmış 18 soru bulunurken, üçüncü ve son bölümde ise personellerin sinizmin bilişsel, duyuşsal ve davranışsal boyutlarının incelenmesine yönelik 13 soru sorulmuştur.

Nepotizm ölçeğinde yer alan 18 sorunun çalışmaya katılan personellere 5'li likert üzerinden cevaplamaları gerektiği belirtilmiștir. Buna göre katılımcılar nepotizm ile ilgili katıldıkları sorulara kesinlikle katılmıyorum (1), katılmıyorum (2), kararsızım (3), katılıyorum (4) ve kesinlikle katılıyorum (5) şeklinde yanıtlanmaları istenmiştir. Örgütsel sinizm ölçeğinde ise personellerin bilişsel, duyuşsal ve davranışsal boyutlarını ölçmek amacıyla yer alan 13 sorunun çalışmaya katılan personellere 5'li likert üzerinden cevaplamaları gerektiği belirtilmiştir. Buna göre katılımcılar örgüt kültürü ile ilgili katıldıkları sorulara kesinlikle katılmıyorum (1), katılmıyorum (2), kararsızım (3), katılıyorum (4) ve kesinlikle katılıyorum (5) şeklinde yanıtlanmaları istenmiştir. verilmiştir:

Örneklemi oluşturan katılımcıların demografik özelliklerine aşağıdaki tabloda yer 
Tablo 2: Demografik Özellikler

\begin{tabular}{|c|c|c|c|}
\hline & & Frekans & Yüzde \\
\hline & Erkek & 61 & 72,6 \\
\hline \multirow{7}{*}{ Cinsiyet } & Bayan & 23 & 27,4 \\
\hline & Toplam & 84 & 100 \\
\hline & & Frekans & Yüzde \\
\hline & $18-25$ & 17 & 20,2 \\
\hline & $26-35$ & 34 & 40,5 \\
\hline & $36-45$ & 26 & 31 \\
\hline & $46-55$ & 7 & 8,3 \\
\hline \multirow[t]{5}{*}{ Yaş } & Toplam & 84 & 100 \\
\hline & & Frekans & Yüzde \\
\hline & Bekar & 41 & 48,8 \\
\hline & Evli & 42 & 50 \\
\hline & Eksik & 1 & 1,2 \\
\hline \multirow[t]{5}{*}{ Medeni Durum } & Toplam & 84 & 100 \\
\hline & & Frekans & Yüzde \\
\hline & Lise/Yüksekokul/Fakülte & 75 & 89,29 \\
\hline & Lisansüstü/Doktora & 8 & 9,5 \\
\hline & Eksik & 1 & 1,2 \\
\hline \multirow[t]{8}{*}{ Öğrenim Durumu } & Toplam & 84 & 100 \\
\hline & & Frekans & Yüzde \\
\hline & 1 Yildan Az & 10 & 11,9 \\
\hline & $1-5$ Y1l & 29 & 34,5 \\
\hline & $6-10 Y_{11}$ & 19 & 22,6 \\
\hline & 11-15 Y1l & 9 & 10,7 \\
\hline & 15 ve Üzeri & 16 & 19 \\
\hline & Eksik & 1 & 1,2 \\
\hline Çalışma Y1lı & Toplam & 84 & 100 \\
\hline
\end{tabular}

Katılımcıların \%72,6'sı erkeklerden, \% 27,4'ü kadınlardan oluşmaktadır. Katılımcıların yaş verileri incelendiğinde, \%40,5'ini 26-35 yaş arası kişilerin oluşturduğu görülmektedir. Bunu \%31 ile 36-45 yaş izlemektedir. Katılımcıların \%50'sinin medeni durumu evlidir. Öğrenim durumu olarak \%89,29'u yüksekokul/fakülte mezunudur. Katılımcıların \%34,5'i 1-5 y1llık, \%22,6'sı 6-10 yıllık iş deneyimine sahiptir.

\section{3. Çalışmada Kullanılan Ölçeklerin Açımlayıcı Faktör Analizi Sonuçları}

Bu bölümde Nepotizm ve Örgütsel Sinizm ölçekleri için KaiserMeyerOlkin (KMO) ölçütü ve Bartlett Küresellik testleri uygulanmış ve sonuçları yer almaktadır. KaiserMeyerOlkin (KMO) ölçütü, verilerin, başka bir ifade ile madde/değişken değerlerinin tutarlılığı için geliştirilen bir yaklaşımdır. KMO, Bartlett'in aksine bir test istatistiği değil, belirtildiği gibi bir ölçüt olarak karşımıza çıkmaktadır. KMO tüm maddelerin/değişkenlerin oluşturduğu veri kümesi için geçerli olma özelliği göstermektedir. Bu istatistik özünde verilerin faktör analitik modeli ile modellenip modellenemeyeceğine ilişkin bir ölçütü önümüze koymaktadır. Bu ölçütün aralıkları ise şu şekilde ifade edilmektedir: 
Tablo 3: Kaiser Meyer Olkin (KMO) Ölçütü Aralıkları

\begin{tabular}{ll}
\hline KMO Değeri & Yorum \\
\hline 0,90 & Mükemmel \\
0,80 & Çok İyi \\
0,70 & Iyi \\
0,60 & Orta \\
0,50 & Zaylf \\
0,50 'nin altı & Kabul Edilemez \\
\hline
\end{tabular}

Bartlett Küresellik testi temelinde değişkenlere ilişkin korelasyon matrisinin, (değişkenler arasında ilişki yoktur varsayımına dayanan) birim matrise karşı test edilme ilkesine dayanmaktadır. $\mathrm{Bu}$ nedenle Bartlett testi korelasyon matrisinin anlamlılığının bir testi olarak karşımıza çıkmaktadır. Bartlett testi bir ki-kare istatistiğidir. Analizde $\mathrm{P}$ değeri $=<0,05$ ise verilerin faktör analizine uygun olduğu kabul edilir (Yurdugül, 2005).

\subsubsection{KaiserMeyerOlkin (KMO) Ölçütü ve Bartlett Küresellik Testi Sonuçları}

84 gözlemden oluşan veri setindeki eksik gözlemler liste silme yöntemi ile elenmiş ve örneklem hacmi 70'e düşürülmüştür. Örgütsel sinizm ölçeğinin KMO ve Bartlett Küresellik Testi sonuçları Tablo 4'de yer almaktadır.

Tablo 4: Sinizm Ölçeği İçin KMO ve Bartlett Testi

\begin{tabular}{lll}
\hline KMO ve Bartlett Testi & \\
\hline Kaiser-Meyer-Olkin Örneklem Uygunluk Ölçütü & 0,841 \\
Bartlett Küresellik Testi & Yaklaşık KiKare & 778,111 \\
& Serbestlik Derecesi & 78 \\
& Anlamlılık & 0 \\
\hline
\end{tabular}

Nepotizm ölçeğinin KMO ve Bartlett Küresellik Testi sonuçları Tablo 5'de yer almaktadır.

Tablo 5: Nepotizm ölçeği için KMO ve Bartlett Küresellik Testi Sonuçları

\begin{tabular}{lll}
\hline KMO ve Bartlett Testi & & \\
\hline Kaiser-Meyer-Olkin Örneklem Uygunluk Ölçütü & & 0,856 \\
Bartlett Küresellik Testi & Yaklaşık Kikare & 687,864 \\
& SD & 120 \\
& Anlamlılık & 0,000 \\
\hline
\end{tabular}

Karagöz ve Kösterelioğlu (2008)'na göre, KMO değeri;

- 0,5-0,69 arasinda ise vasat,

$-0,7-0,79$ arasinda ise iyi,

- 0,80- 0,89 arasında ise çok iyi,

- 0,9-1 arasinda ise mükemmeldir. Burada elde edilen KMO değerleri $(0,841$ ve 0,856$)$ ile çok iyi düzeyde yer almaktadır (Karagöz ve Kösterelioğlu,2008: 85).

Veri setinin faktör analizine uygun olabilmesi için korelasyon matrisinin birim matristen farklı olup olmadığının sınanması gerekir. Bunun için Bartlett Küresellik Testi uygulanır. Bartlett Küresellik Testinde hipotezler;

$\mathrm{H}_{0}$ : Korelasyon matrisi birim matristir.

$\mathrm{H}_{\mathrm{a}}$ : Korelasyon matrisi birim matristen farklıdır.

Veri setimize Bartlett Küresellik testi uyguladığımızda ilgili testin $\mathrm{P}$ değeri $<0,05$ olduğu için $\mathrm{H}_{0}$ hipotezi reddedilir (\%5 anlamlılık düzeyinde). Veri seti faktör analizi için uygundur. 
Örgütsel sinizmin faktör yapısına Tablo 6'da yer verilmiştir.

Tablo 6: Örgütsel Sinizm Ölçeği Faktör Yapısı

\begin{tabular}{ccccccc}
\hline \multicolumn{7}{c}{ Toplam Açılkanan Varyans } \\
\hline \multirow{2}{*}{ Bileşen } & Başlangıc & \multicolumn{3}{c}{ Döndürme Sonras1 } \\
\cline { 2 - 7 } & Özdeğer & $\begin{array}{c}\text { Varyans } \\
\text { Açılama } \\
\text { Yüzdesi }\end{array}$ & $\begin{array}{c}\text { Birikimli } \\
(\%)\end{array}$ & Özdeğer & $\begin{array}{c}\text { Varyans } \\
\text { Açıklama } \\
\text { Yüzdesi }\end{array}$ & $\begin{array}{c}\text { Birikimli } \\
(\%)\end{array}$ \\
\hline 1 & 6,492 & 49,937 & 49,937 & 3,708 & 28,522 & 28,522 \\
2 & 1,827 & 14,054 & 63,991 & 3,285 & 25,270 & 53,792 \\
3 & 1,584 & 12,181 & 76,173 & 2,909 & 22,380 & 76,173 \\
4 & 0,620 & 4,768 & 80,941 & & & \\
5 & 0,581 & 4,470 & 85,411 & & & \\
6 & 0,504 & 3,878 & 89,290 & & & \\
7 & 0,361 & 2,779 & 92,068 & & & \\
8 & 0,317 & 2,441 & 94,509 & & & \\
9 & 0,262 & 2,018 & 96,527 & & & \\
10 & 0,209 & 1,610 & 98,136 & & & \\
11 & 0,166 & 1,277 & 99,413 & & & \\
12 & 0,044 & 0,335 & 99,748 & & & \\
13 & 0,033 & 0,252 & 100,000 & & & \\
\hline
\end{tabular}

13 maddelik 5'li Likert ifadelerinden oluşan Örgütsel sinizm ölçeği veri setimize uygulandığında birbirinden bağımsız üç faktör elde edilmiştir. Üç madde toplam varyansın $\% 76,1$ 'ini açıklamaktadır.

Maddelerin faktörlerde nasıl yüklendiği Tablo 7'de verilmiştir:

Tablo 7: Örgütsel Sinizm Ölçeği Faktör Tablosu

Çalıştığım kurumu/işyerini düşündükçe hiddetlenirim.

Çalıştığım kurumu/işyerini düşündükçe gerilim yaşarım.

Çalıştığım kurumu/işyerini düşündükçe sinirlerim.

Çalıştığım kurumu/işyerini düşündükçe içimi bir endişe kaplar.

Çalıştığım kurumda/işyerinde söylenenlerle yapılanların farklı

olduğuna inanıyorum.

Çalıştığım kurumda/işyerinde yapılacağı söylenen şeylerle

gerçekleșenler arasında çok az benzerlik görüyorum.

Çalıştığım kurumun/işyerinin politika amaç ve uygulamaları arasında

çok az ortak yön vardır.

Çalıştığım kurumda/işyerinde bir uygulamanın yapılacağı söyleniyorsa

bunun gerçekleşip gerçekleşmeyeceği konusunda kuşku duyarım.

Çalıştığım kurumda/işyerinde çalışanlardan bir şey yapmaları beklenir

ancak başka bir davranış ödüllendirilir. Çalışanlara hak ettiği ödül

verilmez.

Başkalarıyla çalıştığım kurumdaki /işyerindeki işlerin nasıl yürütüldüğü

hakkında konuşurum.

Başkalarıyla çalıştığım kurumdaki/işyerindeki uygulamaları ve

politikaları eleştiririm.

Çalıştığım kurumdan /işyerinden ve çalışanlardan bahsedildiğinde

birlikte çalıştığım kişilerle anlamlı bir şekilde bakışırız.

Çalıştığım kurum/işyeri dışındaki arkadaşlarıma işte olup bitenler

konusunda yakınırım.

\begin{tabular}{ccc}
\multicolumn{3}{c}{ Bileşen } \\
\hline 1 & 2 & 3 \\
\hline 0,940 & & \\
0,919 & & \\
0,896 & & \\
0,849 & &
\end{tabular}

0,835

0,804

0,793

0,716

0,672 
Açımlayıcı faktör analizi sonuçları örgütsel sinizm ile ilgili daha önceki çalışmalarla uyumlu biçimde üç faktörde toplanmıştır: 1.faktör duyuşsal, 2.faktör bilişsel, 3.faktör davranışsal boyut olarak adlandırılır.

Tablo 8: Değişkenlere Yönelik Tanımlayıcı İstatistik

\begin{tabular}{ccccc}
\hline Değişkenler & Soru Sayısı & Ortalama & Standart Sapma & $\begin{array}{c}\text { Cronbach'ın } \\
\text { Alfası }\end{array}$ \\
Nepotizm & 13 & 3,4351 & 1,2540 & 0,922 \\
Örgütsel Sinizm & 13 & 2,9912 & 1,3343 & 0,922 \\
Bilişssel Boyut & 5 & 2,9885 & 1,2134 & 0,865 \\
Duyusssal Boyut & 4 & 2,9214 & 1,4555 & 0,966 \\
Davranışsal Boyut & 4 & 3,0643 & 1,3642 & 0,863 \\
\hline
\end{tabular}

Nepotizm ölçeği açımlayıcı faktör analizi ile geçerlenmiş ve iki faktörlü yapı elde edilmiştir. Faktör binişmesi vb. nedenlerle 5 madde silinmiş ve ölçek 13 maddeye indirgenmiştir.

Tablo 9: Korelasyon Matrisi

\begin{tabular}{|c|c|c|c|c|c|}
\hline \multicolumn{2}{|c|}{ Örgütsel Sinizmin Boyutları } & Nepotizm & Duyuşsal & Bilişsel & Davranışsal \\
\hline \multirow[b]{2}{*}{ Nepotizm } & Pearson Korelasyon & 1 & & & \\
\hline & Anlamlılık & & & & \\
\hline \multirow{2}{*}{$\begin{array}{l}\text { Duyuşsal } \\
\text { Boyut }\end{array}$} & Pearson Korelasyon & $-0,219$ & 1 & & \\
\hline & Anlamlılık & 0,068 & & & \\
\hline \multirow{2}{*}{$\begin{array}{l}\text { Bilişsel } \\
\text { Boyut }\end{array}$} & Pearson Korelasyon & $-0,266^{*}$ &, $556^{* *}$ & \multirow[t]{2}{*}{1} & \\
\hline & Anlamlilık & 0,026 & 0,000 & & \\
\hline \multirow[b]{2}{*}{$\begin{array}{l}\text { Davranışsal } \\
\text { Boyut }\end{array}$} & Pearson Korelasyon & $-0,089$ &, $459^{* *}$ & \multirow{2}{*}{$\begin{array}{l}, 562^{* *} \\
0,000\end{array}$} & \multirow[t]{2}{*}{1} \\
\hline & Anlamlılık & 0,464 & 0,000 & & \\
\hline \multicolumn{6}{|c|}{ *. Correlation 0,05 düzeyinde anlaml 1} \\
\hline \multicolumn{6}{|c|}{ **. Korelasyon 0,01 düzeyinde anlamlı } \\
\hline \multicolumn{6}{|c|}{$\begin{array}{l}\text { NORT (nepotizm ölçek ortalaması), DUORT(sinizmin duyuşsal boyutu ölçek ortalaması), } \\
\text { B1ORT(sinizmin bilişsel boyutu ölçek ortalaması) ve DAORT(sinizmin davranışsal boyutu ölçek } \\
\text { ortalaması) değişkenleri için korelasyon matrisi elde edilmiş ve Tablo 9'da verilmiştir. }\end{array}$} \\
\hline \multicolumn{6}{|c|}{ Tablo 10: Hipotezler } \\
\hline \multicolumn{6}{|c|}{ Hipotez } \\
\hline \multicolumn{6}{|c|}{ Nepotizm ile örgütsel sinizmin bilişsel boyutu arasında anlamlı bir ilişki vardır. } \\
\hline \multicolumn{6}{|c|}{ Nepotizm ile örgütsel sinizmin duyuşsal boyutu arasında anlamlı bir ilişki vardır. } \\
\hline \multicolumn{6}{|c|}{ Nepotizm ile örgütsel sinizmin davranışsal boyutu arasında anlamlı bir ilişki vardır. } \\
\hline
\end{tabular}


Nepotizm ile örgütsel sinizmin bilişsel boyutu arasında, anlamlılık düzeyi 0,026 olması nedeniyle anlamlı bir ilişki bulunmaktadır. Ancak pearson korelasyonu negatif olduğu için ilişkinin yönü ters olmaktadır. $\mathrm{H}_{1}$ hipotezi kısmen kabul edilmiştir.

Nepotizm ile örgütsel sinizmin duyuşsal boyutu arasında, anlamlılık düzeyi 0,068 olduğu için anlamlı bir ilişki bulunmamaktadır. $\mathrm{H}_{2}$ hipotezi reddedilmiştir.

Nepotizm ile örgütsel sinizmin davranışsal boyutu arasında, anlamlılık düzeyi 0,464 olması nedeniyle anlamlı bir ilişki bulunmamaktadır. $\mathrm{H}_{3}$ hipotezi reddedilmiştir.

\section{Sonuç}

$\mathrm{Bu}$ çalışmanın temel amacı nepotizm ve örgütsel sinizm ilişkisini incelemektir. Küreselleşme ile birlikte örgütler hızlı bir değişim sürecine girmişlerdir. Bu baş döndürücü hıza uyum sağlayabilenler oyuna dahil olurken diğerleri maalesef silinip gitmektedir. Böylesine çetin bir rekabet ortamında nepotist karaktere sahip olan şirketlerin yeniliklere uyum sağlaması ve çalışanlarının girişimcilik yönlerini teşvik etmesi oldukça güçtür. Bu çalışma günümüz şirketlerinin birçoğunda mevcut çalışanlarını rahatsız eden ve içlerindeki potansiyeli çıkarmasına engel olan nepotizm konusuna ve bununla birlikte duyarsız ve güvensiz çalışanların içinde bulundukları duruma atfedilen örgütsel sinizm konusuna odaklanarak literatüre katkı sağlamayı amaçlamıştır. Bu amaçla oluşturulan nepotizm ile örgütsel sinizmin bilişsel boyutu arasındaki ilişkiyi değerlendirmek için kurulan hipotez şu şekildedir:

$\mathrm{H}_{1}$ : Nepotizm ile örgütsel sinizmin bilişsel boyutu arasında anlamlı bir ilişki vardır.

Çalışmanın örneklemi için nepotizm ile örgütsel sinizmin bilişsel boyutu arasında anlamlı bir ilişki olup, ters yönlüdür. Hipotez kısmen kabul edilmiştir. Nepotizm artıkça örgütsel sinizmin bilişsel boyutu azalmaktadır. Yine aynı şekilde çalışanlar nezdinde örgütsel sinizmin bilişsel boyutu yukarı seviyeye çıktıkça nepotizmin daha az var olduğu sonucu ortaya çıkmaktadır. Diğer bir ifadeyle, nepotizmi çalışanlar kendi iç çalışma gruplarını oluşturması yönüyle düşünsel açıdan kısmen kabul edilebilir görmektedir.

Nepotizm ile örgütsel sinizmin duyuşsal boyutu arasındaki ilişkiyi değerlendirmek için kurulan hipotez şu şekildedir:

$\mathrm{H}_{2}$ : Nepotizm ile örgütsel sinizmin duyuşsal boyutu arasında anlamlı bir ilişki vardır.

Uygulanan Tek Yönlü Varyans Analizi $\mathrm{P}$ değeri $>0,05$ olduğu için hipotezler reddedilmiştir. Hesaplanan korelasyon katsayısı varyans analizi sonucunu destekleyecek şekilde anlamsız bulunmuştur. Çalışmanın örneklemi için nepotizm ile örgütsel sinizmin duyuşsal boyutu arasında anlamlı bir iliş̧i tespit edilememiştir. Hipotez reddedilmiştir. Buradan hareketle çalışmanın örneklemi için nepotizmin, çalışanların duygularını ifade tarzlarında ya da içtenliklerinde herhangi bir değişikliğe neden olmadığı görülmektedir.

Nepotizm ile örgütsel sinizmin davranışsal boyutu arasındaki ilişkiyi değerlendirmek için kurulan hipotez şu şekildedir:

$\mathrm{H}_{3}$ : Nepotizm ile örgütsel sinizmin davranışsal boyutu arasında anlamlı bir ilişki vardır.

Uygulanan Tek Yönlü Varyans Analizi P değeri>0,05 olduğu için hipotez reddedilmiştir. Hesaplanan korelasyon katsayısı varyans analizi sonucunu destekleyecek şekilde düşük şiddette ($0,089)$ bulunmuştur. Çalışmanın örneklemi için nepotizm ile örgütsel sinizmin davranışsal boyutu arasında anlamlı bir ilişki bulunamamıştır. Hipotez reddedilmiştir. Bu bağlamda çalışmanın örnekleminde, nepotizmin çalışanların kuruma karşı olan davranışlarında aşağılayıcı ya da kurumu değersiz olarak gösterme çabasına neden olmadığı söylenebilir.

Sonuç olarak, mevcut çalışmada nepotizm ile örgütsel sinizmin üç boyutu (bilişsel, duyuşsal ve davranışsal) arasındaki ilişki araştırılmıştır. Nepotizmin ile örgütsel sinizmin boyutları 
arasındaki ilişkiyi araştırmak üzere oluşturulan hipotezler ve araştırma sonuçları aşağıdaki tabloda verilmiştir.

Tablo 11: Hipotez Değerlendirme Tablosu

\begin{tabular}{lll}
\hline No & Hipotez adı & Red/Kabul \\
\hline $\mathrm{H}_{1}$ & $\begin{array}{l}\text { Nepotizm ile örgütsel sinizmin bilişsel boyutu arasında anlamlı bir } \\
\text { ilişki vardır. }\end{array}$ & Kısmen Kabul \\
\hline $\mathrm{H}_{2}$ & $\begin{array}{l}\text { Nepotizm ile örgütsel sinizmin duyuşsal boyutu arasında anlamlı bir } \\
\text { ilişki vardır. }\end{array}$ & Red \\
\hline $\mathrm{H}_{3}$ & $\begin{array}{l}\text { Nepotizm ile örgütsel sinizmin davranışsal boyutu arasında anlamlı } \\
\text { bir ilişki vardır. }\end{array}$ & Red \\
\hline
\end{tabular}

Katılımcılar kamu personelidir. Ülkemizde kamu personeli alımı sınavlar ile yapıldığ için işe alımda nepotizm ciddi bir sorun teşkil etmemektedir. Ancak özellikle kamu sektöründe işe alımlardan sonraki aşamalarda örneğin; terfi, ödüllendirme gibi süreçlerde liyakatten ziyade nepotist etki sonucunda alınmış kararlar görülmektedir. Araştırma mevcut çalışanlara yapılmış olup katılımcıların tümü terfi, ödül gibi temel süreçleri yaşamaktadır. Bu bağlamda araştırma; işe alım sonrası süreçlerde nepotizm algısı var mı? Eğer var ise bu algının çalışan üzerinde sinizm açısından bir etkisi olmuş mu? sorularına odaklanmıştır. Ancak eldeki veriler incelendiğinde araştırmaya konu edilen kamu kurumunda bir hipotezin kısmen kabulü dışında böyle bir ilişkinin varlığı reddedilmiştir. Diğer yandan, kamu çalışanlarının işten çıkarılma riskinin özel sektör çalışanlarına göre düşük olması kamu çalışanlarının özel sektör çalışanlarına nazaran daha az sinik düşünce, duygu ve davranış geliştirmesine neden olabilir. Katılımcıların nepotizm ölçeğine verdiği yanıtların 2,94-3,8 aralığında olduğu diğer bir deyişle çok şiddetli bir nepotizm tecrübe etmedikleri görülmektedir. Nepotizm ile sinizm ilişkisini gösteren üç hipotezden ikisinin reddedilmiş olması bir ölçüde katılımcıların nepotizmi çok şiddetli deneyimlememiş olması ile açılanabilir. Bu noktada, örneklemin bölge müdürlüğü çalışanlarından oluşması ve bu kesimin, yapılan işin niteliği gereği liyakat açısından ön planda değerlendirilmesi ile profesyonel yönetimin etkisiyle daha az nepotizm ve sinizm ilişkisi hissettiği yorumu yapılabilir.

Bu çalışma sonucunda ileriki çalışmalar için şu öneriler geliştirilmiştir:

- Bu çalışmada sadece bir kamu kurumunun bölge müdürlüğü baz alınmıştır, bundan sonraki çalışmalarda kamu yerine özel kesime yönelik bir aile işletmesinde çalışma yapılabilir.

- Geçmiş çalışmalarda nepotizmin üç boyutu olduğu görülmektedir. Bunlar; işe almada kayırmacılık, işlem kayırmacılığı ve terfi kayırmacılığıdır. Bu çalışmada nepotizm bütün olarak ele alınmıştır. Kamu çalışanlarının yaşama olasılığı en yüksek nepotizm türü siyasi kayırmacılıktır ki bu durum işe alım aşamasında değil terfi aşamasında daha çok yaşanmaktadır. Kamu çalışanları için terfi kayırmacılığı ile sinizm arasındaki ilişkisi araştırılabilir.

- Nepotizm işletmelerde çok farklı değişkenlere etki edebilir, bu kavramın örgütsel sinizm dışındaki değişkenlerle iliş̧isinin incelenmesi literatüre yeni bilgiler sunabilir.

\section{Kaynakça}

Asunakutlu, T. ve Avc1, U. (2009). "Nepotizm-İş Tatmini İlişsisi: Aile İşletmelerinde Bir İnceleme", 17. Ulusal Yönetim ve Organizasyon Kongresi, Osmangazi Üniversitesi İ̈BF İşletme Bölümü, Eskişehir. https://doi.org/10.17494/ogusbd.88512

Brandes, P., Dharwadkar, R., \& Dean, J. W. (1999). Does organizational cynicism matter? Employee and supervisor perspectives on work outcomes. In Eastern Academy of Management Proceedings, 2, 150-153. 
Büte, M. (2011). Kayırmacılığın Çalışanlar Üzerine Etkileri İle İnsan Kaynakları Uygulamaları İlişkisi: Türk Kamu Bankalarına Yönelik Bir Araştırma/The Relationship Between the Effects of Nepotism on the Employees and Human Resource Practices: A Research on Turkish Publ. Atatürk Üniversitesi Sosyal Bilimler Enstitüsü Dergisi, 15(1), 383-404. https://doi.org/10.20875/makusobed.290644

Dean Jr, J. W., Brandes, P., \& Dharwadkar, R. (1998). Organizational cynicism. Academy of Management review, 23(2), 341-352. https://doi.org/10.5465/amr.1998.533230

Özkanan, A., \& Erdem, R. (2014). Yönetimde kayırmacı uygulamalar: kavramsal bir çerçeve. Süleyman Demirel Üniversitesi Sosyal Bilimler Enstitüsü Dergisi, (20), 179-206.

Özüren, Ü. (2017). Tekstil işletmelerinde nepotizm uygulamalarına bağlı olarak üretkenlik karşıtı davranışlar ve sonuçları (Doctoral dissertation, İstanbul Kültür Üniversitesi/SosyalBilimler Enstitüsü/İşletme Anabilim Dalı/İşletme Bilim Dal1).

Eryeşil, K., Fındık M. (2011). “Örgütsel Sinizm”, Örgüt Psikolojisi Yeni Yaklaşımlar ve Güncel Konular", Edt: Aykut Bedük, Atlas Akademi, Konya, 97-118.

Gövez, E. (2013). Örgütsel Sinizm ve Dönüştürücü/Etkileşimci Liderlik Arasındaki İlişki-Bir Uygulama. Atatürk Üniversitesi, Sosyal Bilimler Enstitüsü, Yüksek Lisans Tezi, Erzurum.

Gül, H.; Ağı̈öz, A. (2011). "Mobbing ve Örgütsel Sinizm Arasındaki İlişkiler”, Afyon Kocatepe Üniversitesi İ̈BF Dergisi. 8(3), 27-47.

James, M. S. L. (2005). Antecedents and Consequences of Cynicism in Organizations: An Examination of the Potential Positive and Negative Effects on School Systems. Retrieved from http://purl.flvc.org/fsu/fd/FSU_migr_etd-3639.

Johnson, J. L., \& O'Leary-Kelly, A. M. (2003). The effects of psychological contract breach and organizational cynicism: Not all social exchange violations are created equal. Journal of Organizational Behavior: The International Journal of Industrial, Occupational and Organizational Psychology and Behavior, 24(5), 627-647. https://doi.org/10.1002/job.207

Karagöz Y., Kösterelioğlu İ. (2008), "İletişim Becerileri Değerlendirme Ölçeğinin Faktör Analizi Metodu İle Geliştirilmesi”, Dumlupınar Üniversitesi Sosyal Bilimler Dergisi, 21, 81-98.

Karakaş, M., \& Çıçek, H. (2009). Vergi Yükümlülerinin Yolsuzluğa İlişkin Tutum ve Tepkileri: Gaziantep Örneği. Sosyoekonomi, 9(1), 48-76.

K1lıç, S. (2013). Örnekleme yöntemleri. Journal of Mood Disorders, 3(1), 44-6.

Kiechel, W. (1984). How to relate to nepotism. Fortune, 119, 143-144

Polat, G. (2012). Örgütlerde nepotizmin örgütsel adalet algısı ile ilişkisinin tespitine yönelik bir araştırma. (Unpublished master's thesis) Dumlupınar University, Institute of Social Sciences, Istanbul.

Polatcan, M., (2012). “Okul Yöneticilerinin Liderlik Davranışları İle Öğretmenlerin Örgütsel Sinizm Tutumları Arasındaki İlişki,” Yüksek Lisans Tezi, Sakarya Üniversitesi, Eğitim Bilimleri Enstitüsü, Sakarya.

Tokgöz, N., Yılmaz, H. (2008). “Örgütsel sinizm: Eskişehir ve Alanya'daki otel işletmelerinde bir uygulama” Anadolu üniversitesi Sosyal Bilimler Dergisi, 8(2), 238-305. https://doi.org/10.18506/anemon.408477

Yurdugül, H. (2005), Faktör Analizinde KMO ve Bartlett Testleri Neyi Ölçer?, Hacettepe Üniversitesi Yayınları, Ankara.

Yıldırım, M . (2013). Kamu yönetiminin kadim paradoksu: nepotizm ve meritokrasi. Celal Bayar $\begin{array}{llllll}\text { Üniversitesi Sosyal Bilimler } & \text { Dergisi, } & 11 & \text { (2), 353-380. }\end{array}$ https://doi.org/10.18026/cbusos.11047 